\title{
Mindsets of Current Entrepreneurial and Imminent Labour Forces in Chakan and Mumbai: A Comparative Study
}

\author{
D.O.I - 10.51201/12497 \\ https://doi.org/10.51201/12497
}

Dr. Dipti Vashisth Sharma

Associate Professor, Marwadi University, Rajkot

Prof. Sarita Samson

Assistant Professor, ATSS College of Business Studies and Computer Applications, Pune

\begin{abstract}
This paper is focused on the concept of Game theory, which producesoptimal decision-making of independent and competing actors in a strategic setting; we have designed hypothetical questions as a part of an online survey. Our respondents were (adults and students). Putting them in a critical economic situation, we asked them to answer a series of questions that would help us determine their mindsets, and form our raw data.
\end{abstract}

Keywords: Entrepreneurial, Imminent Labour Forces,Game Theory

\section{Introduction:}

Game Theory

Game theory is a theoretical structure or a roadmap to understand situation among competing players and their behavior to understand and study strategic decision making among individuals. This helps to know the action should perform by a player which would help him increase his change of success.

Game theory is about the detailed study of cooperation and conflict or grievances. This theory concept we can apply when the actions of players are independent. The agenda of game theory is to provide structure and try to understand strategic situations.

The theoretical part of Game Theory is based on a game, which is

- Game: Any interaction between multiple people in which each person's payoff is affected by the decisions made by others.

- Players: A strategic decision-maker within the context of the game 
- Strategy: A complete plan of action a player will take given the set of circumstances that might arise within the game

- Payoff: The payout a player receives from arriving at a particular outcome (The payout can be in any quantifiable form, from dollars to utility)

- Information set: The information available at a given point in the game (The term information set is most usually applied when the game has a sequential component.)

Game theory: Branch of applied mathematics that was initially developed by an American Mathematician John von Neumann and his colleague Oscar Morgenstern, a German Economist, to solve economic problems. Game theory provides tools for analyzing situations in which parties; called players, make decisions that are interdependent. This interdependence causes each player to consider the other player's possible decisions, or strategies, in formulating his own strategy. A solution to a game describes the optimal decisions of the players, who may have similar, opposed, or mixed interests, and the outcomes that may result from these decisions. In other words, a firm or individual considers the decisions of other firms or individuals while making their own.

Let's take prisoner's dilemma as an example. Consider that 2 players, Alice and Bob, are plausible suspects to a crime. The Judge tries to play it smart and separates Alice and Bob in 2 rooms. Assuming that both of them do not get time to talk to each other and that both are rational decision makers, who are not related by blood, they are each given 2 options: Remain Silent or Confess. If both Alice and Bob choose to remain silent, both serve 1 year in prison. If they both confess, both serve 3 years in prison. However, if Alice confesses and Bob remains silent, Bob serves 5 years in jail and Alice goes free, and vice versa.

Although, theoretically, both suspects remaining silent are the best outcome, it is not the realistic one. Because the suspects have an incentive to blame the other suspects for the crime, their decision will be in pursuit of self-interest, eventually compelling them to choose the worst outcome. If Alice chooses to confess, it is in Bob's interest to confess too. If Alice chooses to remain silent, Bob should still confess to go free. Irrespective of Alice's decision, it is in Bob's interest to confess. This is a dominant strategy: optimum move for an individual regardless of how the other players act. Similarly, it is in Alice's interest to confess regardless of Bob's decision, which makes the outcome when both of them confess an example of a Nash 
Equilibrium, which is the optimal outcome of a game is one where no player has an incentive to deviate from his chosen strategy after considering an opponent's choice.

\section{Psychology:}

Economic Theories are based on two critical assumptions, one of them being "Rational Economic Decision Making" or "rational self-interest". This means that individuals are assumed to make decisions in their best self-interest, continually trying to maximize the satisfaction that they receive from their financial decisions. Example: It can be assumed that producers would try to maximize the profits they obtain from their business; workers would work at a place they receive the highest wage along with high job satisfaction.

Although in the real world, due to each individual's "cultural baggage" these assumptions may not always prevail. A plethora of factors affect the ability and willingness of an individual to make rational financial decisions including age, socioeconomic status, cognitive biases, and past experiences. It is essential to understand how the above-listed factors affect one's ability to make rational decisions.

Past Experiences can have a significant impact on one's decision. If in the past, a similar arrangement has led to a positive output, individuals are motivated to make a similar decision, which might not be ideal given the current circumstances. Similarly, if the individual may have made a failed decision in the past, he/she might not invest in the present opportunity, even if it has an extremely high prospect of achieving success.

A cognitive bias is a systematic error in one's thought process that occurs when individuals process and interpret information in the world around them, and base their decisions on them. Biases can prove to disrupt $\&$ distort objective contemplation of a particular situation by introducing various influences into the process of making decisions. Most individuals are usually entirely unaware of biases that may alter their judgment. The two most common cognitive biases include the halo effect and anchoring.

The halo effect refers to one's general or overall impression of a company or another individual. It influences their thoughts about the company's overall skills and properties. For example, if one performs well in a particular area we tend to believe that the individual would perform well in another area, even if the areas/topics aren't related. Anchoring refers to the over-dependence of people on an initial experience or piece of data. We tend to make all other decisions based on the 
same information/experience around the "anchor" or initial encounter. This in turn hinders our ability to interpret and understand new information which may prove to be valuable.

Recent experiments have proved that emotions may have a significant impact on our ability to think logically. Each emotion creates a powerful yet different impact on each individual. For Example, Anger may motivate some people to work more cautiously and may demotivate an entrepreneur to take risks. Although in some cases it may instil the concept of "revenge" in some entrepreneurs, in which case the entrepreneur might even be willing to make a loss as long as he feels that he is mentally satisfied.

Hence it is essential to keep in mind the various factors that might affect an individual's ability to think rationally to understand the various types of entrepreneurial behaviour.

\section{Who do our respondents and their home-city symbolize?}

Students symbolize the impending labour force, and the adults are generalized as the current labour force. In this investigation, Mumbai represents the urban lifestyle and mindset; whereas, Chakan mirrors the relatively rural region.

\section{Objective of the study}

1. To know and understand the economic perspective of the students.

2. to study and compare their mindsets with the people

\section{Hypotheses:}

Hypothesis 1 - Students based in Chakan will look to gain their individual benefit, looking at the situation through an economic perspective. If required, in the journey of individual benefit, they will break the agreement and their partner's trust.

Hypothesis 2 - Adults who own or work in a company in Chakan will look to gain their benefit to some extent. They will not stab their partner in the back and break a formal agreement.

Hypothesis 3 - Students in Mumbai will also look to gain their individual benefit, looking at the situation through an economic perspective. If required, in the journey of individual benefit, they will break the agreement and their partner's trust.

Hypothesis 4 - Owners or Employees of a Mumbai-based company will look to gain their own benefit. They would consider but not mind breaking the trust of their partner, forming a dominant strategy,

\section{Research Methodology}


This study is based on Primary and secondary data. Researcher framed a questionnaire and collected information from various respondents.

\section{Scope of the study}

This study will help multi-disciplinary researchers in expanding their knowledge about the stateof-the-art in game theory. It will also help researchers to look at game-theoretic literature analyzed from the perspective of different agents or players.

\begin{tabular}{|c|c|c|c|}
\hline What is your name? & $\begin{array}{l}\text { What } \\
\text { is } \\
\text { your } \\
\text { age? }\end{array}$ & $\begin{array}{l}\text { Assuming that Vodafone makes a } \\
\text { rational decision following your } \\
\text { decision, which of the } 2 \text { options will } \\
\text { you choose, and why? }\end{array}$ & $\begin{array}{l}\text { Would you stick with the } \\
\text { agreement or choose a } \\
\text { different option, and why? }\end{array}$ \\
\hline \multicolumn{4}{|c|}{ Students from Mumbai } \\
\hline PratyayAgrawal & 17 & $\begin{array}{l}\text { Advertise. This is basically game } \\
\text { theory and according to economists, } \\
\text { if the other person/company is } \\
\text { unknown you should 'advertise' }\end{array}$ & $\begin{array}{l}\text { Yes, I will stick with the } \\
\text { agreement because I am a } \\
\text { man of my word. }\end{array}$ \\
\hline jimin $\mathrm{k}$ & 18 & $\begin{array}{l}\text { I will advertise assuming that } \\
\text { Vodafone will also advertise to gain } \\
\text { profits. I would not want to lose my } \\
\text { market share to Vodafone, so } \\
\text { advertising would be in my interest. }\end{array}$ & $\begin{array}{l}\text { If I am not legally bound to } \\
\text { follow the agreement, I will } \\
\text { probably advertise to } \\
\text { increase my profits. }\end{array}$ \\
\hline RehonGanguli & 17 & $\begin{array}{l}\text { Advertise because that would yield } \\
\text { me extra money and Airtel will make } \\
\text { more profit. In any case, I would } \\
\text { advertise to gain more money }\end{array}$ & $\begin{array}{l}\text { I will stick because of my } \\
\text { reputation as the CEO. }\end{array}$ \\
\hline RamaswamyMuthiah & 17 & $\begin{array}{l}\text { I would choose to advertise because } \\
\text { the profit could potentially be higher } \\
\text { at a risk of } \$ 10 \mathrm{~m} \text {. I'd rather take a } \\
\text { risk to benefit more. }\end{array}$ & $\begin{array}{l}\text { I will not stick as Airtel will } \\
\text { earn more money }\end{array}$ \\
\hline
\end{tabular}




\begin{tabular}{|c|c|c|c|}
\hline RohanReddi & 17 & $\begin{array}{l}\text { I would choose to advertise. If I don't } \\
\text { I will make only } 20 .\end{array}$ & $\begin{array}{l}\text { I would choose to stick with } \\
\text { the agreement. Since if the } \\
\text { decision is taken many } \\
\text { times the best outcome for } \\
\text { both parties is to get } 50 \\
\text { every time. I would choose } \\
\text { to trust Airtel. }\end{array}$ \\
\hline Vihaan & 18 & $\begin{array}{l}\text { Advertise because rational behaviour } \\
\text { would mean choosing to do best for } \\
\text { your company. Advertise for to } \\
\text { increase profits.. }\end{array}$ & $\begin{array}{l}\text { Break the agreement and go } \\
\text { ahead and advertise. This is } \\
\text { a smart option because the } \\
\text { competitor also has a chance } \\
\text { to break the agreement. }\end{array}$ \\
\hline Tejas & 17 & $\begin{array}{l}\text { Advertise since product promotion } \\
\text { would anyways increase the sales of } \\
\text { the company in the long run. }\end{array}$ & $\begin{array}{l}\text { Not Stick, because that's } \\
\text { the most profitable outcome. } \\
\text { If I don't, they'll also } \\
\text { eventually infringe the } \\
\text { contract, reducing profits to } \\
\text { lower than originally. }\end{array}$ \\
\hline Niketakhanna & 16 & $\begin{array}{l}\text { I would choose to advertise because I } \\
\text { would rather take the risk of } \\
\text { Vodafone also advertising than not } \\
\text { advertising at all. Even if Vodafone } \\
\text { does advertise the outcome for me } \\
\text { would be better than if I don't } \\
\text { advertise at all. }\end{array}$ & $\begin{array}{l}\text { I would stick with the } \\
\text { agreement as it's important } \\
\text { to keep up to your word and } \\
\text { seems like the right thing to } \\
\text { do as a businessman. And to } \\
\text { maintain my reputation. }\end{array}$ \\
\hline Arjun & 17 & $\begin{array}{l}\text { Advertise as it would anyways lead to } \\
\text { the promotion of my product. }\end{array}$ & $\begin{array}{l}\text { I would not stick to the } \\
\text { agreement. It is the most } \\
\text { profitable outcome. }\end{array}$ \\
\hline
\end{tabular}




\begin{tabular}{|c|c|c|c|}
\hline PranavSagar & 17 & $\begin{array}{l}\text { Since both parties are rational the } \\
\text { Nash equilibrium will be achieved. } \\
\text { Therefore I will choose to advertise. } \\
\text { No matter what Vodafone decides to } \\
\text { do, advertising will be a more } \\
\text { profitable outcome for me than not } \\
\text { advertising. }\end{array}$ & $\begin{array}{l}\text { I wouldn't stick to the } \\
\text { agreement due to the } \\
\text { prospect of earning a higher } \\
\text { profit. }\end{array}$ \\
\hline Shefali & 17 & $\begin{array}{l}\text { Well, this is game theory. So out of } \\
\text { the two options I'd choose to } \\
\text { advertise and ensure Vodafone } \\
\text { doesn't. Solely because the incentive } \\
\text { to cheat is high: by advertising, } \\
\text { Not only can Airtel expand their } \\
\text { customer base (as advertising raises } \\
\text { consumer awareness etc.), it is the } \\
\text { most monetary profitable outcome as } \\
\text { well(INR } 70 \text { million). }\end{array}$ & $\begin{array}{l}\text { I wouldn't agree, as } \\
\text { although formal collusion } \\
\text { seems to be the safer option, } \\
\text { it isn't in the consumer's } \\
\text { best interests. What this } \\
\text { means is it can potentially } \\
\text { backfire and result in the } \\
\text { loss of consumer loyalty for } \\
\text { Airtel, which in the short } \\
\text { term may not seem like a } \\
\text { big issue (as INR } 50 \text { million } \\
\text { seems like a good deal to } \\
\text { compensate) but in the long } \\
\text { run, it can be detrimental to } \\
\text { the profit margins of airtel. } \\
\text { And as mentioned, Airtel } \\
\text { has no personal ties to } \\
\text { Vodafone, so realistically } \\
\text { there's no determining what } \\
\text { ulterior motive Vodafone } \\
\text { has, apart from 'most } \\
\text { profitable outcome" for both } \\
\text { companies. }\end{array}$ \\
\hline
\end{tabular}




\begin{tabular}{|c|c|c|c|}
\hline AnirbanDutta & 17 & $\begin{array}{l}\text { I will advertise, because if I don't } \\
\text { decide to advertise Vodafone walks } \\
\text { away with a } 70 \text { million profit whereas } \\
\text { my profit decreases. }\end{array}$ & $\begin{array}{l}\text { I would stick with the } \\
\text { agreement because the cell } \\
\text { phone data market is very } \\
\text { elastic and it is easy for } \\
\text { consumers to switch. } \\
\text { Therefore, I will collude on } \\
\text { different levels to capture } \\
\text { more of the market. And it } \\
\text { would aid my reputation as } \\
\text { a CEO. }\end{array}$ \\
\hline Gaayen & 17 & $\begin{array}{l}\text { Advertising as any kind of promotion } \\
\text { would anyways aid my sales. }\end{array}$ & $\begin{array}{l}\text { Wouldn't stick as I would } \\
\text { get more profit }\end{array}$ \\
\hline rishasirdeshmukh & 16 & $\begin{array}{l}\text { I would advertise because I can't } \\
\text { guarantee that vodaphone will choose } \\
\text { not to advertise and so this option } \\
\text { involves the least risk. }\end{array}$ & $\begin{array}{l}\text { I would not stick to the } \\
\text { agreement since this is the } \\
\text { most profitable option for } \\
\text { my firm. }\end{array}$ \\
\hline \multicolumn{4}{|c|}{ Students from Chakan } \\
\hline RajviBagdai & 19 & $\begin{array}{l}\text { In order for Airtel to gain some of } \\
\text { their market share back they need to } \\
\text { advertise as it is profitable }\end{array}$ & $\begin{array}{l}\text { Stick to the agreement } \\
\text { because clearly it is the } \\
\text { most profitable. Hopefully } \\
\text { Vodafone sees it the same } \\
\text { way. }\end{array}$ \\
\hline PritShobhana & 17 & $\begin{array}{l}\text { Would choose to advertise because in } \\
\text { that case Airtel either ways earns a } \\
\text { profit so would be beneficial to them } \\
\text { if only they advertise or Vodafone } \\
\text { follows to do so too. }\end{array}$ & $\begin{array}{l}\text { I would choose a different } \\
\text { option, and break the } \\
\text { agreement because that } \\
\text { would be beneficial for my } \\
\text { company by increasing our } \\
\text { profits }\end{array}$ \\
\hline
\end{tabular}




\begin{tabular}{|c|c|c|c|}
\hline Vishnu Sojitra & 18 & $\begin{array}{l}\text { Assuming that Vodafone makes a } \\
\text { rational decision after my decision, } \\
\text { according to me (the owner of Airtel), } \\
\text { I would go with advertising for my } \\
\text { company. The reason behind this is, } \\
\text { by advertising for Airtel, I would gain } \\
\text { a huge profit, profit in millions, } \\
\text { which would be appreciated by my } \\
\text { company's shareholders, having the } \\
\text { sole aim for profit maximization. }\end{array}$ & $\begin{array}{l}\text { Yes, I would stick to that } \\
\text { agreement, as being the } \\
\text { owner of such a reputable } \\
\text { company I have my own } \\
\text { responsibilities } \\
\text { reputation to maintain. } \\
\text { Sticking to the agreement } \\
\text { will help me sustain my } \\
\text { decision rationally and } \\
\text { ethically. }\end{array}$ \\
\hline AaryanParmar & 17 & $\begin{array}{l}\text { Advertise because I can profit the } \\
\text { most in that situation }\end{array}$ & $\begin{array}{l}\text { I will break the agreement } \\
\text { and get most of the market } \\
\text { share. }\end{array}$ \\
\hline DevKalaria & 17 & $\begin{array}{l}\text { Advertise. If i don't then vodafone } \\
\text { takes off more profit which is bad for } \\
\text { my company. To collect my extra } \\
\text { profit, i will advertise. }\end{array}$ & $\begin{array}{l}\text { I will trust Vodafone to not } \\
\text { break the agreement as we } \\
\text { can share the market } 50-50 \\
\text { without incurring costs, } \\
\text { unless a third competitor } \\
\text { gets in the market. }\end{array}$ \\
\hline ayush p & 18 & $\begin{array}{l}\text { According to game theory, } \\
\text { advertising is the most viable option } \\
\text { so as to getting more profit }\end{array}$ & $\begin{array}{l}\text { Definitely break the } \\
\text { agreement and advertise so I } \\
\text { can get more customers and } \\
\text { earn more profit. }\end{array}$ \\
\hline Darsh Parekh & 19 & $\begin{array}{l}\text { Advertise because by paying } \\
\text { 10million } \mathrm{i} \text { am not risking anything. } \\
\text { Way safer and profitable }\end{array}$ & $\begin{array}{l}\text { Break because there's } \\
\text { higher profit. ( } 70 \text { millon) }\end{array}$ \\
\hline harmitRathod & 18 & $\begin{array}{l}100 \% \text { advertise as that is yielding } \\
\text { more profit }\end{array}$ & $\begin{array}{l}\text { As my dad has told me, trust } \\
\text { is one of the most important } \\
\text { factors in business and so I }\end{array}$ \\
\hline
\end{tabular}




\begin{tabular}{|c|c|c|c|}
\hline & & & $\begin{array}{l}\text { will not break the agreement } \\
\text { and show Vodafone the } \\
\text { benefits of sticking with the } \\
\text { agreement also. }\end{array}$ \\
\hline NityaJadeja & 17 & $\begin{array}{l}\text { Advertise to increase awareness } \\
\text { about my company in the market and } \\
\text { create presence by showing all the } \\
\text { products my company specialises in. }\end{array}$ & $\begin{array}{l}\text { I will not break the } \\
\text { agreement because my } \\
\text { reputation will tarnish. It } \\
\text { would be morally wrong to } \\
\text { break an agreement when } \\
\text { decided on it. }\end{array}$ \\
\hline Diya G & 18 & $\begin{array}{l}\text { I will advertise because that is the } \\
\text { nash equilibrium based on game } \\
\text { theory. Irrespective of opponent's } \\
\text { move, it is important to advertise. }\end{array}$ & $\begin{array}{l}\text { Betray Vodafone becausewe } \\
\text { are rivals and if I can get an } \\
\text { opportunity to make more } \\
\text { profit, I will take it as soon } \\
\text { as I can }\end{array}$ \\
\hline DevanshuMakwana & 18 & $\begin{array}{l}\text { Won't risk to not advertise as } \\
\text { Vodafone can advertise anytime and } \\
\text { get a higher market share. (70million) } \\
\text { Whereas I (airtel) will be left with } \\
\text { lesser amount(20million) }\end{array}$ & $\begin{array}{l}\text { Will not collude and go } \\
\text { ahead and advertise as that } \\
\text { gives me more money by } \\
\text { taking most of the market } \\
\text { share. Will be very difficult } \\
\text { for Vodafone to come back } \\
\text { then. }\end{array}$ \\
\hline YuvrajFinava & 18 & $\begin{array}{l}\text { Advertise as it has more profit for my } \\
\text { company }\end{array}$ & $\begin{array}{l}\text { I will believe that Vodafone } \\
\text { doesn't break the agreement } \\
\text { and neither would I because } \\
\text { in the long term it is better } \\
\text { for the both of us. }\end{array}$ \\
\hline ShreeyaTilva & 17 & $\begin{array}{l}\text { Advertise as I will lose less and gain } \\
\text { more. Although it is lesser than } 50\end{array}$ & $\begin{array}{l}\text { I will choose a different } \\
\text { option because that has }\end{array}$ \\
\hline
\end{tabular}




\begin{tabular}{|l|l|l|l|l|} 
& & $\begin{array}{l}\text { million, it is better to get } 40 \text { million } \\
\text { than to get } 20 \text { million }\end{array}$ & $\begin{array}{l}\text { more scope for earning } \\
\text { profits which could then be } \\
\text { used elsewhere. }\end{array}$ \\
\hline Diyakotecha & 17 & $\begin{array}{l}\text { I would choose advertising as its } \\
\text { more money in my pocket and my } \\
\text { employees. }\end{array}$ & $\begin{array}{l}\text { I will choose the other } \\
\text { option because then there is } \\
\text { more money that goes in my } \\
\text { pocket and my employees } \\
\text { can get a raise. }\end{array}$ \\
\hline Riya & $\begin{array}{l}\text { I would choose to advertise because } \\
\text { position and products will only be } \\
\text { recognizable if I advertise. }\end{array}$ & $\begin{array}{l}\text { I will have an incentive to } \\
\text { cheat in order to capture } \\
\text { more market share, and get } \\
\text { higher returns because from } \\
\text { the most optimistic point if I } \\
\text { advertise and if Vodafone } \\
\text { doesn't then I am likely to } \\
\text { gain } 70 \text { million and so the } \\
\text { best option is to break the } \\
\text { agreement and advertise. }\end{array}$ \\
\hline
\end{tabular}

\begin{tabular}{|c|c|c|c|c|}
\hline $\begin{array}{l}\text { What is your } \\
\text { name? }\end{array}$ & $\begin{array}{l}\text { What } \\
\text { is } \\
\text { your } \\
\text { age? }\end{array}$ & $\begin{array}{l}\text { Name of the } \\
\text { company } \\
\text { you } \\
\text { own/work } \\
\text { for? }\end{array}$ & $\begin{array}{l}\text { Assuming that Vodafone } \\
\text { makes a rational decision } \\
\text { following your decision, } \\
\text { which of the } 2 \text { options will } \\
\text { you choose, and why? }\end{array}$ & $\begin{array}{l}\text { Would you stick with the agreement } \\
\text { or choose a different option, and } \\
\text { why? }\end{array}$ \\
\hline \multicolumn{5}{|c|}{ Adults from Chakan } \\
\hline Nirav shah & 42 & RGS & $\begin{array}{l}\text { To advertise as its good for a } \\
\text { solid reputation and also } \\
\text { attracts new futuristic } \\
\text { customers }\end{array}$ & $\begin{array}{l}\text { If the Ideology matches there is no } \\
\text { harm in making a harmonious } \\
\text { scenario in terms of plans offered to } \\
\text { customers and so on. It all depends }\end{array}$ \\
\hline
\end{tabular}




\begin{tabular}{|c|c|c|c|c|}
\hline & & & & $\begin{array}{l}\text { on the principles on which the } \\
\text { business stands. }\end{array}$ \\
\hline $\begin{array}{l}\text { Ajay } \\
\text { bagdai }\end{array}$ & 47 & $\begin{array}{l}\text { Chaitanya } \\
\text { cine world } \\
\text { Pvt ltd }\end{array}$ & $\begin{array}{l}\text { If I am making a rational } \\
\text { decision, I will advertise to } \\
\text { aim for highest profit }\end{array}$ & $\begin{array}{l}\text { Stick to agreement because } \\
\text { hopefully Vodafone can see it from } \\
\text { my point of view as the best } \\
\text { outcome for the both of us }\end{array}$ \\
\hline $\begin{array}{l}\text { Manish } \\
\text { Kalaria }\end{array}$ & 50 & $\begin{array}{l}\text { Star balls \& } \\
\text { rollers pvt } \\
\text { ltd }\end{array}$ & $\begin{array}{l}\text { Option to advertise to earn } \\
\text { the most benefit instead of } \\
\text { waiting for vodafone to } \\
\text { benefit }\end{array}$ & $\begin{array}{l}\text { Yes, as for long term you need to do } \\
\text { business with ethics and if we break } \\
\text { the agreement, eventually my } \\
\text { competitor will know it. So why do } \\
\text { that }\end{array}$ \\
\hline $\begin{array}{l}\text { AMISH } \\
\text { CHANDAR } \\
\text { ANA }\end{array}$ & 34 & $\begin{array}{l}\text { Chandarana } \\
\text { Intermediari } \\
\text { es Brokers } \\
\text { Pvt. Ltd. }\end{array}$ & $\begin{array}{l}\text { Advertise because that is the } \\
\text { maximum profit outcome }\end{array}$ & $\begin{array}{l}\text { Stick with the agreement as if I } \\
\text { make an agreement it will be right } \\
\text { in terms of the profitability and if } \\
\text { we have agreed on it I am pretty } \\
\text { sure Vodafone wont break it }\end{array}$ \\
\hline $\begin{array}{l}\text { Manish } \\
\text { Motiani }\end{array}$ & 41 & $\begin{array}{l}\text { DLP } \\
\text { INDUSTRIE } \\
\text { S LLP }\end{array}$ & $\begin{array}{l}\text { I would choose to continue } \\
\text { advertising, customer } \\
\text { memory is very limited. The } \\
\text { only way to remain relevant } \\
\text { is to continue being in the } \\
\text { customers mind, and also to } \\
\text { eliminate the threat of losing } \\
\text { market share, in case a third } \\
\text { player enters the market. }\end{array}$ & $\begin{array}{l}\text { If i stick I will not earn more profit } \\
\text { so I would choose not to stick by } \\
\text { any agreement, } \\
\text { "Stopping advertising to save } \\
\text { money is like stopping your watch } \\
\text { to save time." - Henry Ford. }\end{array}$ \\
\hline $\begin{array}{l}\text { prashantvithl } \\
\text { ani }\end{array}$ & 46 & $\begin{array}{l}\text { individual } \\
\text { investor as } \\
\text { well partner } \\
\text { in companies }\end{array}$ & $\begin{array}{l}\text { will go with first option, } \\
\text { advertise, because in such } \\
\text { competitive market one } \\
\text { should take risk of losing }\end{array}$ & $\begin{array}{l}\text { Agreements are based on faith. } \\
\text { Hence, I will not break as it is a } \\
\text { great outcome for both. }\end{array}$ \\
\hline
\end{tabular}




\begin{tabular}{|c|c|c|c|c|}
\hline & & $\begin{array}{l}\text { named } \\
\text { reckon } \\
\text { infra.,renaiss } \\
\text { anceconst.,li } \\
\text { nen club }\end{array}$ & margin to other rival & \\
\hline Atul & 50 & $\begin{array}{l}\text { Sheth } \\
\text { Builders }\end{array}$ & $\begin{array}{l}\text { Advertise because it is a must } \\
\text { to make your ideas stick }\end{array}$ & $\begin{array}{l}\text { Trusting your partner in an } \\
\text { agreement is the most important } \\
\text { thing. Eventhough we are rivals, } \\
\text { according to this agreement we } \\
\text { become partners. }\end{array}$ \\
\hline Vimal & 42 & Airtel ;) & 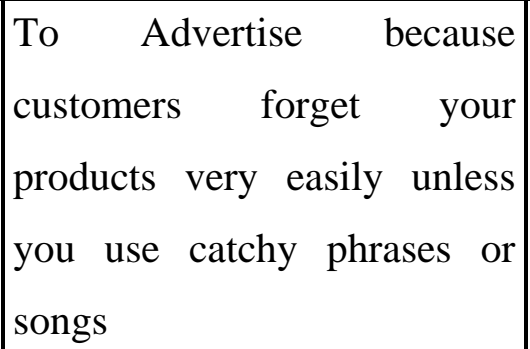 & $\begin{array}{l}\text { Assuming that Vodafone sticks to } \\
\text { its agreement, I will also stick. }\end{array}$ \\
\hline $\begin{array}{l}\text { Bharat } \\
\text { Hapani }\end{array}$ & 45 & Kich Group & $\begin{array}{l}100 \% \text { advertise because } \\
\text { "Half the money I spend on } \\
\text { advertising is wasted' the } \\
\text { trouble is I don't know which } \\
\text { half" John Wanamaker }\end{array}$ & $\begin{array}{l}\text { Yes, I will fulfill my Commitment } \\
100 \% \text { because I trust vodafone, } \\
\text { although they are my rivals. }\end{array}$ \\
\hline Mitul K & 43 & $\begin{array}{l}\text { Star rollers } \\
\text { and bearings }\end{array}$ & $\begin{array}{l}\text { advertise to attract my } \\
\text { targeted customers }\end{array}$ & $\begin{array}{l}\text { firstly will not go with the } \\
\text { agreement and if at all go then } \\
\text { would stick to it because ethics are } \\
\text { more important }\end{array}$ \\
\hline $\begin{array}{l}\text { Rajesh } \\
\text { Nathwani }\end{array}$ & 45 & IMS & $\begin{array}{l}\text { Advertise to increase demand } \\
\text { for airtel services in the } \\
\text { telecommunications industry }\end{array}$ & $\begin{array}{l}\text { If you look at it from Rajkot's view, } \\
\text { everyone makes an agreement only } \\
\text { on trusting and so will I. }\end{array}$ \\
\hline
\end{tabular}




\begin{tabular}{|c|c|c|c|c|}
\hline $\begin{array}{l}\text { MauleshUka } \\
\text { ni }\end{array}$ & 50 & Ban Labs & $\begin{array}{l}\text { Advertise because advertising } \\
\text { is imp }\end{array}$ & $\begin{array}{l}\text { Never make the agreement but if I } \\
\text { do I will trust myself and vodafone } \\
\text { to have made the right decision. }\end{array}$ \\
\hline $\begin{array}{l}\text { RajanVadali } \\
\text { a }\end{array}$ & 45 & $\begin{array}{l}\text { Vadalia } \\
\text { Foods }\end{array}$ & $\begin{array}{l}\text { Advertise to increase sales } \\
\text { and make my product stand } \\
\text { out in the industry }\end{array}$ & $\begin{array}{l}\text { Stick to the agreement because I } \\
\text { will value my position as CEO and } \\
\text { also ethics play a big role. }\end{array}$ \\
\hline $\begin{array}{l}\text { chintansitapa } \\
\text { ra }\end{array}$ & 39 & galaxy gears & $\begin{array}{l}\text { I will definitely choose } \\
\text { advertising otherwise people } \\
\text { won't know that airtel exists }\end{array}$ & $\begin{array}{l}\text { Stick to the agreement because I } \\
\text { trust Vodafone as partners in an } \\
\text { agreement }\end{array}$ \\
\hline Nirajaarya & 47 & Utkarshtmt & $\begin{array}{l}\text { Option No. 1: To advertise. } \\
\text { Because, as a businessman, I } \\
\text { will surely aim to grab } \\
\text { maximum potential of market } \\
\text { share }\end{array}$ & $\begin{array}{l}\text { Stick because I believe the right } \\
\text { decision would have been made, } \\
\text { giving both of us a handsome } \\
\text { amount. }\end{array}$ \\
\hline \multicolumn{5}{|c|}{ Adults from Mumbai } \\
\hline Neha Jain & $39 y r d$ & $\begin{array}{l}\text { Indo } \\
\text { Containers } \\
\text { Pvt Ltd }\end{array}$ & $\begin{array}{l}\text { 1) I would certainly advertise } \\
\text { to refrain my existing } \\
\text { customers from kindling any } \\
\text { desire to strike any } \\
\text { comparison with my rival and } \\
\text { swapping over to their } \\
\text { product } \\
\text { This would ensure their } \\
\text { continued support and trust in } \\
\text { our quality. }\end{array}$ & $\begin{array}{l}\text { If we have mutually agreed to } \\
\text { sustain the agreement, then I would } \\
\text { like to go ahead with that. The } \\
\text { market being an oligopolistic one, } \\
\text { competitors are just a handful, } \\
\text { although big . So, word of } \\
\text { commitment should hold good and } \\
\text { in all probability upheld by the } \\
\text { competitor too. This would ensure a } \\
\text { healthy atmosphere for both in } \\
\text { future too. }\end{array}$ \\
\hline
\end{tabular}




\begin{tabular}{|c|c|c|c|c|}
\hline Saroj S & $\begin{array}{l}69 \\
\text { yrs }\end{array}$ & $\begin{array}{l}\text { HitechBlow } \\
\text { mouldersPvt } \\
\text { Ltd }\end{array}$ & $\begin{array}{l}\text { Advertising for sure! Risk } \\
\text { taking is a vital factor in } \\
\text { every undertaking. However } \\
\text { calculated risks are much } \\
\text { safer with a certain assured } \\
\text { profit. To boost sales and } \\
\text { growth in business, a steady } \\
\text { and stable progress is the key. }\end{array}$ & $\begin{array}{l}\text { Agreement on non- advertising with } \\
\text { your competitor though sounds } \\
\text { good, however, cannot be } \\
\text { completely relied upon. A slight } \\
\text { change in protocols may be } \\
\text { sufficient reason for the rival to } \\
\text { obliterate the agreement. So it } \\
\text { would be better if I will prepare to } \\
\text { advertise than wait and watch }\end{array}$ \\
\hline $\begin{array}{l}\text { SMRITI } \\
\text { Sethia }\end{array}$ & $\begin{array}{l}\text { 39yea } \\
\text { rs }\end{array}$ & $\begin{array}{l}\text { FACET58 } \\
\text { jewellery Co } \\
\text { Pvt Ltd }\end{array}$ & $\begin{array}{l}\text { Advertise. Since promoting } \\
\text { the product would anyways } \\
\text { help the sales revenue. }\end{array}$ & $\begin{array}{l}\text { No, I would not stick to obtain } \\
\text { higher market share. }\end{array}$ \\
\hline $\begin{array}{l}\text { NeelamAgar } \\
\text { wal }\end{array}$ & 41 & Tatva & $\begin{array}{l}\text { Advertise, i stand to get } 40 \\
\text { million no matter what ( } 70 \\
\text { best case). In the other case } \\
\text { there's a possibility to drop } \\
\text { down to } 20 \text { million. }\end{array}$ & $\begin{array}{l}\text { I would certainly stick due to ethical } \\
\text { reasons. }\end{array}$ \\
\hline Rohit & 44 & $\begin{array}{l}\text { KanikaIspat } \\
\text { Pvt Ltd }\end{array}$ & $\begin{array}{l}\text { I would definitely go in for } \\
\text { advertising my Brand cauz in } \\
\text { the long run it will definitely } \\
\text { give me results.....Jo } \\
\text { DikthaHaiWohBiktaHai }\end{array}$ & I would stick due to ethical reasons. \\
\hline IshanBajoria & 29 & $\begin{array}{l}\text { Trambak } \\
\text { Rubber } \\
\text { Industries } \\
\text { Ltd. }\end{array}$ & 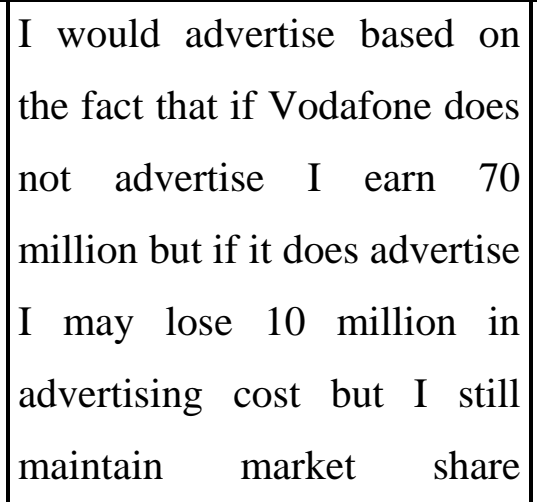 & $\begin{array}{l}\text { I would not stick with the } \\
\text { agreement because based on } \\
\text { assumption that Vodafone would } \\
\text { not opt to stick to the agreement as } \\
\text { well. The chance and risk of } \\
\text { advertising and earning the } \\
\text { additional } 20 \text { million is more }\end{array}$ \\
\hline
\end{tabular}




\begin{tabular}{|c|c|c|c|c|}
\hline & & & $\begin{array}{l}\text { equally and still earn revenue } \\
\text { of } 40 \text { million and do not give } \\
\text { up an established market. }\end{array}$ & $\begin{array}{l}\text { rewarding and safe in comparison to } \\
\text { not advertising and loosing market } \\
\text { share completely and dropping } \\
\text { revenue to } 30 \text { million. }\end{array}$ \\
\hline $\begin{array}{l}\text { ShyamMend } \\
\text { a }\end{array}$ & 44 & $\begin{array}{l}\text { WIPRO } \\
\text { LTD }\end{array}$ & $\begin{array}{l}\text { Advertise, as i will also be } \\
\text { promoting my product which } \\
\text { would help me in the long } \\
\text { run. }\end{array}$ & $\begin{array}{l}\text { stick with the agreement as long } \\
\text { advodafone is also sticking to it and } \\
\text { because of ethical reasons }\end{array}$ \\
\hline Dev Gupta & 44 & $\begin{array}{l}\text { Strapp } \\
\text { Business } \\
\text { Solution Pvt. } \\
\text { Ltd. }\end{array}$ & $\begin{array}{l}\text { Advertise, as promoting my } \\
\text { product would help me in the } \\
\text { long run. }\end{array}$ & Stick due to ethical reasons. \\
\hline Sidharth S & 44 & $\begin{array}{l}\text { Indo } \\
\text { containers } \\
\text { pvt ltd }\end{array}$ & $\begin{array}{l}\text { I would definitely advertise } \\
\text { because customer should be } \\
\text { aware of the brand which will } \\
\text { help in introducing new } \\
\text { products at a later date }\end{array}$ & $\begin{array}{l}\text { would definitely stick to the } \\
\text { agreement because in long term } \\
\text { various situations would arise if } \\
\text { there is no trust in service providers } \\
\text { customers would take Advantage, } \\
\text { secondly being ethical is important }\end{array}$ \\
\hline KritikaBaid & 29 & $\begin{array}{l}\text { Solicitor } \\
\text { firm }\end{array}$ & $\begin{array}{l}\text { Advertise as I would stand to } \\
\text { make a higher profit but } \\
\text { mainly due to promotional } \\
\text { activities. }\end{array}$ & $\begin{array}{l}\text { If I agree, it implies I have the } \\
\text { intention to do so, so I would stick } \\
\text { to it }\end{array}$ \\
\hline Sandeep & 44 & KPEPL & $\begin{array}{l}\text { Advertise as promotion } \\
\text { usually leads to higher sales } \\
\text { in the long run. }\end{array}$ & $\begin{array}{l}\text { stick to the agreement for ethical } \\
\text { reasons }\end{array}$ \\
\hline
\end{tabular}




\begin{tabular}{|c|c|c|c|c|}
\hline $\begin{array}{l}\text { Nikita } \\
\text { Bajoria }\end{array}$ & 29 & $\begin{array}{l}\text { Trambak } \\
\text { Rubber } \\
\text { Industries } \\
\text { Ltd. }\end{array}$ & $\begin{array}{l}\text { I would advertise based on } \\
\text { the fact that if Vodafone does } \\
\text { not advertise I earn } 70 \\
\text { million but if it does advertise } \\
\text { I may loose } 10 \text { million in } \\
\text { advertising cost but I still } \\
\text { maintain market share } \\
\text { equally and still earn revenue } \\
\text { of } 40 \text { million and do not give } \\
\text { up an established market. }\end{array}$ & $\begin{array}{l}\text { I would stick to the agreement } \\
\text { because of ethical restraints. }\end{array}$ \\
\hline
\end{tabular}

\begin{tabular}{|l|l|l|l|l|}
\hline $\begin{array}{l}\text { Rahul } \\
\text { Tripathi }\end{array}$ & 42 & $\begin{array}{l}\text { Tripathi } \\
\text { Industries }\end{array}$ & $\begin{array}{l}\text { Advertise. Since promoting } \\
\text { my product would anyways } \\
\text { help me. }\end{array}$ & $\begin{array}{l}\text { Business Ethics is something that is } \\
\text { very important to me, I would stick. }\end{array}$ \\
\hline Sanjay Baid & $\begin{array}{l}\text { Baid Blow- } \\
\text { moulders }\end{array}$ & $\begin{array}{l}\text { Advertise. Since promotion } \\
\text { would aid in the long run. }\end{array}$ & $\begin{array}{l}\text { I would stick since my reputation } \\
\text { as ethical company would help } \\
\text { me in the future. }\end{array}$ \\
\hline Alok Parekh & $\begin{array}{l}\text { Parekh } \\
\text { Automobile } \\
\text { s }\end{array}$ & $\begin{array}{l}\text { Advertise, since only what is } \\
\text { seen is sold. }\end{array}$ & $\begin{array}{l}\text { I would stick, since clients also } \\
\text { prefer doing business with a } \\
\text { company that is known to be } \\
\text { ethical }\end{array}$ \\
\hline
\end{tabular}

\section{Data Analysis:}

The analysis of our responses was divided by the 2 reason-based questions that the respondents were supposed to answer in our form.

\section{Question 1:}

As seen by the responses, every student and adult from both Chakan and Mumbai chose the option to advertise; however, their reason to do so made all the difference. In the situation, it was indeed the best option to advertise, an option chosen by every respondent. The reasons to 
advertise were split in 2 different categories: Profit and Promotion. If a respondent chose to advertise for promoting his product, he was thinking about the long-term prospect of his product and was actually considering the benefits of advertising. On the other hand, the respondents who chose to advertise for profits limited their thinking to the data provided by us and did not think from an analytical point of view.

Similarly,

\section{Question 2:}

The answer to the second question was the main determinant of the Entrepreneurial Mindset of the respondents. All the responses received were divided into 3 categories: Stick because of trust, Stick because of ethics and reputation as CEO, and Do not stick to earn more profit. A response that chose to stick because of trust shows that the person is trustworthy and expects their partner to reciprocate. This type of person is very optimistic about anything from his business decision to his expectation of his competitor's business decision. A person who chooses to stick because of ethics cares about his image in the market and believes in integrity, something that, in the future, would yield him respect and loyalty, not only from his competitors but also his employees. Lastly, if a person chooses to not stick, he is striving for profit and is in the pursuit of his individual benefit. This person would most likely be a person who if given the chance to be a partner in a firm would put his benefit first. He would also be a type of person who might not trust anybody but himself.

\section{Graph 1}

Responses by students (Chakan and Mumbai) in Question 1

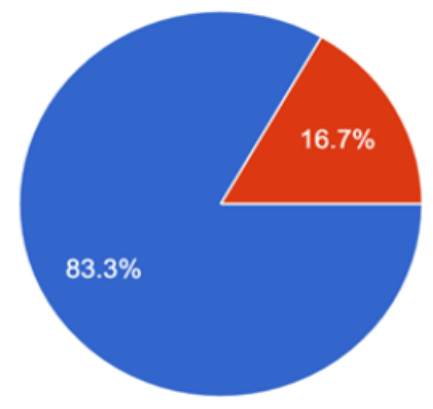


It was noticed that the responses of Students of Chakan and Mumbai were fairly similar, compelling us to compile their responses together and display it in one Graph. A plausible explanation for these similar responses could be the similarity of education they receive and their lack of hands on experience in the market. The data shown by Graph 1 states that $83.3 \%$ of students chose to advertise for profit; whereas $16.7 \%$ chose to spread their product by promoting it.

It can be inferred that the majority of the students did not think about the actual benefits of advertising and reasoned out their choice using the data present in the form. A small portion of the students, however, thought for the long-term betterment of their product.

Another significant observation in the data was that most of the students used theoretical words like 'Game Theory' or 'rational.' These words allude to the fact that the thinking and reasoning of these students was confined to the knowledge they have received from the textbook or their teacher. The use of these words also implied that they have less or no experience working or owning a company.

Graph 2

Responses by students (Chakan and Mumbai) in Question 2

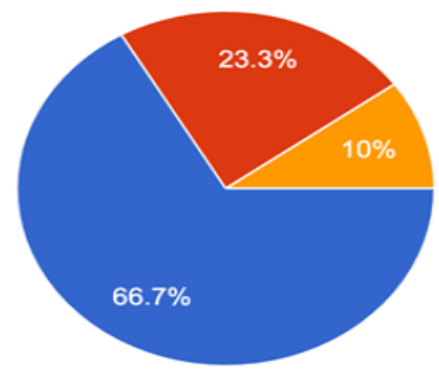

Don't stick for profits

Stick for ethics and reputation

Stick because of trust

Graph 2 - So, the majority of the students do not stick, signifying that in order to gain individual benefit, they would be ready to stab their competitor in the back. This means the impending labour force is not trustworthy and strives for maximum individual profit. However, there are high chances that their ideologies can change once they get an experience of how the real world 
functions. In the future, they would make mistakes or learn from someone else's mistakes, which would influence their choice and shape their mindset.

\section{Graph 3}

Responses by adults in Mumbai

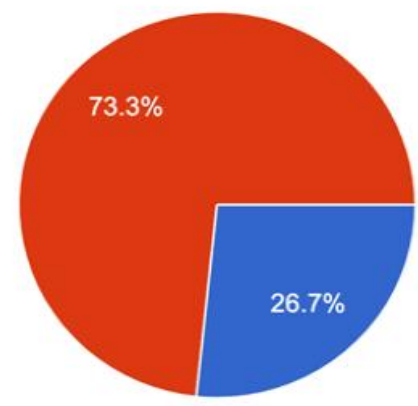

Advertise for Profit

Advertise to Promote the Product

Graph 3 displays the data for Adults in Mumbai for Question 1.73.3\% of the adults in Mumbai wanted to advertise to promote their product. This means a majority of the adults reasoned their choice using the actual benefits of advertising, some of which include increased demand and higher profits in the long run. Although their choice was also to advertise and they also strove for profits, their motive was long-term profits, something that is evident by their reasoning.

Graph 4

Responses by adults in Mumbai in Question 2

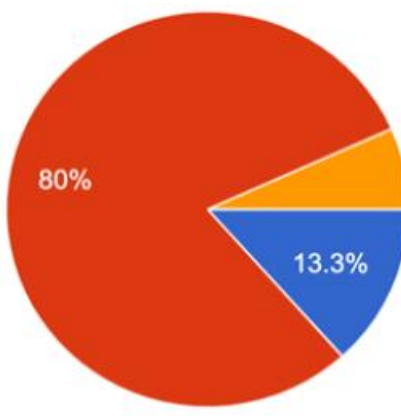

Don't stick for profits

Stick for ethics and reputation

Stick because of trust

Graph 4 shows that $80 \%$ of the Adults in Mumbai chose to stick for ethics, $6.7 \%$ chose to stick because of trust, and $13.3 \%$ chose to not stick, for profit. A very large portion of the respondents cared about their reputation in the market, and perhaps thought that as a CEO, they have a 
reputation to maintain, one that is probably more important than short-term profit. This aids us to generalize that the majority of the businessmen in Mumbai care about their stature and influence in the market. The fact that they consider their prestige to be above all else elucidates that they meticulously evaluate the outcomes, risks, and the people affected following their decision. This highlights their pensive and calculative nature, underlining their journey to short-term profit.

\section{Graph 5}

Responses Adults in Chakan for Question 1

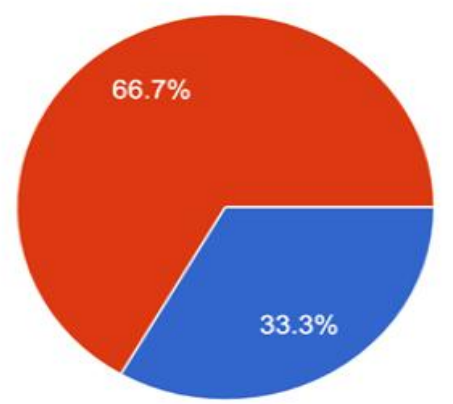

Advertise for Profit

Advertise to Promote the Product

Graph 5 shows $66.7 \%$ of adults choosing to advertise to promote their product. The adults in Chakan hence thought in a similar way to the adults in Mumbai for Question 1. Their main goal was to promote their product and not increase their profits, something that exhibited the importance of advertising in their perspective. The reason why the adults chose to make people aware of their product could be justified by a potential bias because of any past experience or knowledge they have had working in their own field or noticing other firms. For example, in the past, if an owner lost a part of his market share to his competitor because the competitor advertised, the owner is more likely to choose 'advertise to promote his product' as an option in the form.

Graph 6

Response by adults from Chakan for Question 2 


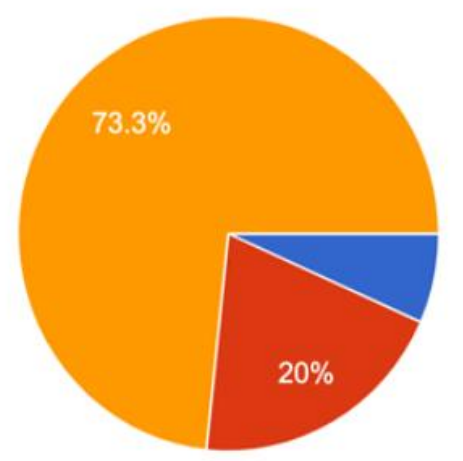

Don't stick for profits

Stick for ethics and reputation

Stick because of trust

Graph 6 shows that $73.3 \%$ respondents chose to stick because of trust, $20 \%$ chose to stick for their reputation, and $6.7 \%$ chose to not stick in order to gain more profits. As visible by the data presented in the graph, the majority of the Adults in Chakan is trustworthy and expects their competitor to reciprocate the same. Having had a business in Chakan, I can say with certainty that most Punekar (in Chakan) completely base their business or investments off trust in the other person. In fact, there are people in Chakan who invest huge sums of money in start-ups based in Chakan, solely due to trust.

\section{Findings:}

1.Majoritystudent and adult from both Chakan and Mumbai chose the option to advertise.

2. Majority of the students did not think about the actual benefits of advertising and reasoned out their choice using the data present in the form.

3. The students used theoretical words like 'Game Theory' or 'rational.' These words allude to the fact that the thinking and reasoning of these students was confined to the knowledge they have received from the textbook or their teacher.

4. The impending labour force is not trustworthy and strives for maximum individual profit. However, there are high chances that their ideologies can change once they get an experience of how the real world functions.

5. $73.3 \%$ of the adults in Mumbai wanted to advertise to promote their product. This means a majority of the adults reasoned their choice using the actual benefits of advertising, some of which include increased demand and higher profits in the long run.

6. $80 \%$ of the Adults in Mumbai chose to stick for ethics, $6.7 \%$ chose to stick because of trust, and $13.3 \%$ chose to not stick, for profit. A very large portion of the respondents cared about their reputation in the market. 
7. The majority of the Adults in Chakanare trustworthy and expect their competitor to reciprocate the same

\section{Limitations of the study}

- All the respondents were owners of big companies or renowned businessmen in their respective cities, thereby leading to a biased generalisation of the entire current labour forces of Chakan and Mumbai

- Results were based on a small sample size which could have made the percentages of the graphs less accurate.

- Past experiences or personal affiliations could have hindered the collection of accurate and reliable data, hence, affecting the analysis.

- Some responses lacked reasoning. Consequently, those respondents were requested to fill the forms again, this time with their reasoning.

- Respondents were all from different industries yielding different responses to the given pressuring situation

\section{References:}

1. Brams, Steven J., and Morton D. Davis. "Game Theory." Encyclopadia Britannica, Encyclopadia Britannica, Inc., 10 Jan. 2020, www.britannica.com/science/game-theory.

2. Chen, James. "Nash Equilibrium." Investopedia, Investopedia, 2 Mar. 2020, www.investopedia.com/terms/n/nash-equilibrium.asp.

3. Cherry, Kendra. "Types of Cognitive Biases That Influence Your Thinking and Beliefs." Verywell Mind, 2020, www.verywellmind.com/cognitive-biases-distort-thinking-2794763.

4. Hayes, Adam. How Game Theory Works. 9 July 2020, www.investopedia.com/terms/g/gametheory.asp.

5. Hayes, Adam. How Game Theory Works. 9 July 2020,www.investopedia.com/terms/g/gametheory.asp.

6. https://www.youtube.com/watch?v=MHS-htjGgSY

7. Lerner, Jennifer s. Emotion and Decision Making, 2004, scholar.harvard.edu/files/jenniferlerner/files/annual_review_manuscript_june_16_final.fi $n a l \_p d f$. 
8. Li, Tiantian, et al. "Does Emotion Affects Our Ability To Make Rational Decisions?" The Decision Lab, 1 Oct. 2019, thedecisionlab.com/insights/health/emotion-affects-ourability-rational-decisions/.

9. Majaski, Christina. "Comparing Dominant Strategy Solution vs. Nash Equilibrium Solution." Investopedia, Investopedia, $24 \quad$ Apr. 2020, www.investopedia.com/ask/answers/071515/what-difference-between-dominant-strategysolution-and-nash-equilibrium-solution.asp.

10. Schuck, Carsten, et al. "Figure 2.5: Payoff Matrix in the Prisoner's Dilemma. The First Entry in..." ResearchGate, 19 Dec. 2017, www.researchgate.net/figure/Payoff-matrix-inthe-Prisoners-Dilemma-The-first-entry-in-the-parenthesis-denotes_fig4_251808852.

11. Skeffington, Jennifer Sheehy. How Poverty Affects People's Decision-Making Processes 2007, www.lse.ac.uk/business-and-consultancy/consulting/assets/documents/howpoverty-affects-peoples-decision-making-processes.pdf. 